\title{
Exigências nutricionais de codornas ${ }^{1}$
}

\author{
Nutritional requirements of quais
}
SILVA, José Humberto Vilar²; JORDÃO FILHO, José ; COSTA, Fernando Guilherme Perazzo $^{3}$; LACERDA, Patrícia Barbosa de ${ }^{4}$; VARGAS, Danilo Gonçalves Vieira ${ }^{5}$; LIMA, Matheus Ramalho ${ }^{5}$

\footnotetext{
${ }^{1}$ Revisão apresentada no Congresso Brasileiro de Zootecnia (ZOOTEC 2011).

${ }^{2}$ Universidade Federal da Paraíba, Centro de Ciências Sociais e Agrárias, Departamento de Agropecuária, Bananeiras, Paraíba, Brasil.

${ }^{3}$ Universidade Federal da Paraíba, Centro de Ciências Agrárias, Departamento de Zootecnia, Areia, Paraíba, Brasil.

${ }^{4}$ Universidade Federal da Paraíba, Centro de Ciências Sociais e Agrárias, Programa de Pós-Graduação em Zootecnia, Bananeiras, Paraíba, Brasil.

${ }^{5}$ Programa de Doutorado Integrado em Zootecnia da UFPB/UFRPE/UFC, Areia, Paraíba, Brasil.

*Endereço para correspondência: vilardasiva@yahoo.com.br
}

\section{RESUMO}

As exigências nutricionais de codornas diferem das de frangos e de galinhas poedeiras. Igualmente, as exigências de codornas japonesas também são distintas das de codornas europeias. Codornas exigem mais proteína (aminoácidos), menos cálcio na ração e digerem melhor os aminoácidos dos alimentos em comparação e a energia de alimentos fibrosos. Esses animais ainda aproveitam a energia do milho e do farelo de soja na mesma proporção que os frangos. Da mesma forma que os frangos, as codornas exigem mais energia para mantença, quando alojadas no piso, e menos, quando submetidas às altas temperaturas ambiente. Conclui-se que rações formuladas para frangos e galinhas não devem ser usadas na alimentação de codornas europeias e japonesas.

Palavras-chave: desempenho, nutrição, postura, produção de ovos.

\section{SUMMARY}

The nutritional requirements differ between quail chickens and laying hens and between Japanese quail and European quails. Quail require more protein (amino acids), less calcium and digest better amino acids of food in comparison with chickens, however, quails digest better energy of food fibrous, but in the same proportion as the chickens from corn and soybean meal. Likewise the chickens, the quail require more energy when on the floor and less when subjected to high ambient temperatures. It is concluded that diets for broiler chickens and should not be used as feed for European quails and Japanese.

Keywords: egg production, nutrition, performance.

\section{INTRODUÇÃO}

O Brasil é o quinto maior produtor mundial de carne de codornas e o segundo de ovos. De 2005 para 2006, o alojamento cresceu $12,5 \%$ nas diversas regiões do país, fato que coincide com o surgimento das grandes criações automatizadas e novas formas de comercialização do ovo e da carcaça de codornas (SILVA \& COSTA, 2009). A criação comercial de codornas teve início em 1989, quando uma grande empresa avícola brasileira resolveu implantar o primeiro criatório no Sul do Brasil e só, 
recentemente, as primeiras exportações de carcaças congeladas de codornas foram realizadas.

A alimentação afeta os custos de produção das codornas desde a base, a indústria do melhoramento genético, até o topo da cadeia produtiva, os abatedouros e frigoríficos. Ao considerar que as rações de codornas contêm mais proteína que as rações de frangos e poedeiras, o custo de alimentação das codornas por unidade de produto carne ou ovos é, supostamente, maior. Entretanto, à medida que o conhecimento em nutrição evolui, as dietas são formuladas com custo mínimo e máximo retorno econômico. Silva et al. (2006) demonstraram que a suplementação com metionina de rações, cuja proteína foi reduzida em $20 \%$ (28 para $22,4 \%$ de 1 a 21 e de 24 para $19,2 \%$ de 22 a 42 dias), promoveu ganho e conversão alimentar em codornas europeias semelhante ao controle.

Embora as codornas utilizem a energia do milho e do farelo de soja de forma semelhante aos frangos e galinhas, as exigências nutricionais daquelas são muito diferentes das últimas aves. Por razões óbvias, não é aconselhável alimentar codornas com rações de frangos e galinhas, porque as codornas exigem mais proteína (aminoácidos) e menos cálcio na ração.

As codornas japonesas têm sido melhoradas para alta produção de ovos mais nutritivos, de melhor qualidade e com menor teor de colesterol (MINVIELLE \& OGUZ, 2002), enquanto as codornas pesadas têm sido selecionadas para alta taxa de ganho nas primeiras quatro semanas (AGGREY et al., 2003). Portanto, novas pesquisas com codornas, na área de nutrição, têm surgido na literatura nacional e internacional, a partir do início deste século. Segundo Garcia et al. (2005), nenhuma tabela tem sido publicada desde a edição de 1994 do
NRC, o que evidencia a necessidade de novas informações.

Esta revisão foi elaborada com o objetivo de atualizar as recomendações nutricionais para codornas, sem deixar de considerar os resultados experimentais publicados no Brasil e no exterior.

\section{EXIGÊNCIAS DE CODORNAS DO GENÓTIPO JAPONÊS EM CRESCIMENTO}

O gasto com alimentação é o mais representativo da criação de codornas, de modo que a proteína e a energia contribuem com quase a totalidade desse custo. O ótimo desempenho de codornas depende da interação complexa entre a nutrição e uma variedade de fatores internos (genética, sexo, estágio fisiológico, doenças e bem-estar) e externos ao corpo da ave (temperatura, densidade, higiene, debicagem e vacinações) (SILVA et al., 2004).

A eficiência com que a codorna japonesa retém proteína e energia no corpo aumenta com a idade (SILVA et al., 2004ab), mas é sempre menor se comparada àquela da codorna europeia, em crescimento, e de outras espécies de aves como frangos e galinhas, em crescimento e postura. (JORDÃO FILHO et al., 2011ab). Essa menor eficiência de retenção ajuda a explicar as variações nas exigências das codornas em relação a outras espécies de aves e corrobora a hipótese de Silva \& Costa (2009) de que as codornas devem ser alimentadas com rações formuladas, ao considerar as exigências de cada linhagem.

As codornas japonesas, quando alojadas no piso, apresentam maior demanda de energia para mantença que codornas alojadas em gaiolas, em função do maior espaço disponível para a ave 
expressar livremente o comportamento da espécie na vida selvagem como andar, ciscar, correr e voar (SILVA et al., 2004b; JORDÃO FILHO et al., 2011a).

Oscilações na densidade de alojamento típica das criações comerciais (95 a $160 \mathrm{~cm}^{2} /$ ave) podem não afetar o ganho de peso (SILVA et al., 2007) e a produção de ovos em codornas (LOPES et al., 2006), mas, o alojamento, em baixa densidade $\left(1089 \mathrm{~cm}^{2} / \mathrm{ave}\right)$, ou em piso, comparado às gaiolas (JORDÃO FILHO et al., 2011a) estimula o ganho de peso das codornas.

As codornas japonesas, em crescimento, apresentam um comportamento alimentar típico de frangos e poedeiras, quando mantidas em condições de alta temperatura, isto é, reduzem o consumo voluntário. Segundo Silva et al. (2007), o aumento em $1^{\circ} \mathrm{C}$ acima de 18 até $28^{\circ}$
C diminui o consumo de ração em 83 $\mathrm{mg} / \mathrm{ave} / \mathrm{dia}$ (Figura 1). Lima et al. (2009) também observaram que o consumo de ração caiu de 100 para 88 mg em codornas japonesas alojadas dos 20 a 37 dias de idade em ambiente com 25 e $34^{\circ} \mathrm{C}$.

Em frangos de corte, de 8 a 21 dias de idade, Silva et al. (2009) verificaram aumento na ingestão da ração quando as aves foram submetidas à temperatura ambiente de $22^{\circ} \mathrm{C}$, em comparação com a temperatura de $32^{\circ} \mathrm{C}$. Todavia, a temperatura controle $\left(27^{\circ} \mathrm{C}\right)$ repercutiu em melhor ganho de peso. Jordão Filho et al. (2011a) observaram redução da exigência de energia de mantença com o aumento da temperatura ambiente, o que explica a menor necessidade de gasto de energia pelas aves para produção de calor e, assim, manter a homeotermia corporal.

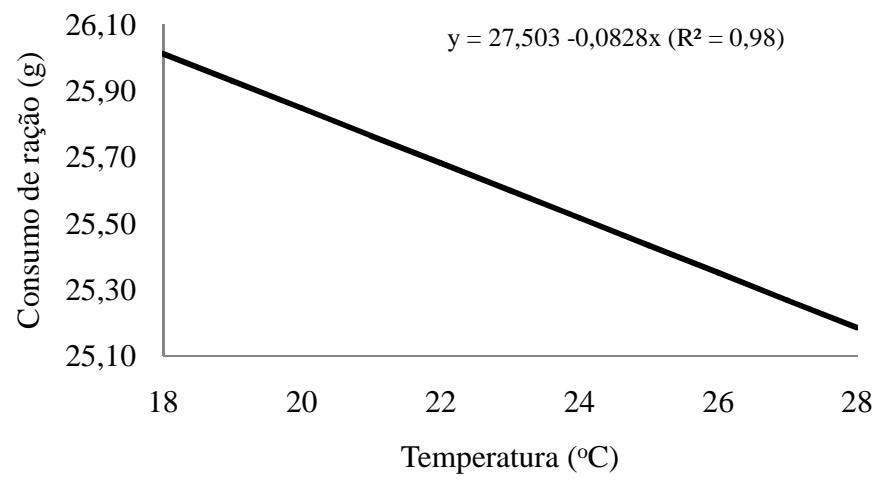

Figura 1. Consumo de ração de codornas japonesas em função da temperatura ambiente

As codornas, como outras espécies de aves, modulam o consumo de ração em função da temperatura e da densidade de energia da dieta. Silva \& Costa (2009) propuseram dois modelos de predição para estimar as exigências de energia metabolizável (EM) em codornas japonesas, com base no peso corporal (PC), no ganho de peso (GP) e na temperatura (T) ambiental: EM $(\mathrm{kcal} / \mathrm{ave} / \mathrm{dia})=\mathrm{PC}^{0,75 *}(98,37-0,205 * \mathrm{~T})$ $+9,0 * \mathrm{GP}$.

Para estimar a exigência de EM, em codornas com peso médio de $0,17 \mathrm{~kg}$, com ganho de peso diário de $5 \mathrm{~g}$ e temperatura ambiente de $25^{\circ} \mathrm{C}$, a equação descrita foi: $\mathrm{EM}=0,17^{0,75 *(98,37-0,205 * 25)+9,0 * 5=}$ $70 \mathrm{kcal}$, que, ao considerar uma dieta com 
Rev. Bras. Saúde Prod. Anim., Salvador, v.13, n.3, p.775-790 jul./set., 2012 http://www.rbspa.ufba.br ISSN 15199940

$2.800 \mathrm{kcal} / \mathrm{kg}$ de EM, resulta num consumo de ração estimado de 25g/ave/dia. Portanto, por razões práticas, a relação caloria: nutriente foi utilizada como critério básico no balanceamento de rações para codornas. Reduções no consumo com o aumento da energia da ração, por exemplo, têm sido relatadas em trabalhos com codornas em crescimento (ELANGOVAN et al., 2004) e em postura (ELANGOVAN et al., 2004; FREITAS et al., 2005; KADAM et al., 2006).

Ao avaliar o comportamento das aves
(Figura 2) até o final da segunda semana de idade, observou-se que as codornas não alteraram o consumo em função do nível de energia da ração, mas após os 14 dias, as rações mais densas $(2.800$ e $2.900 \mathrm{kcal})$ começaram a deprimir mais o consumo e, após 21 dias, o consumo da ração com 2.800 kcal EMAn ultrapassou o consumo da ração com 2.900kcal EMAn. Na Tabela 1 , constam as recomendações de energia e de proteína para codornas japonesas em crescimento.

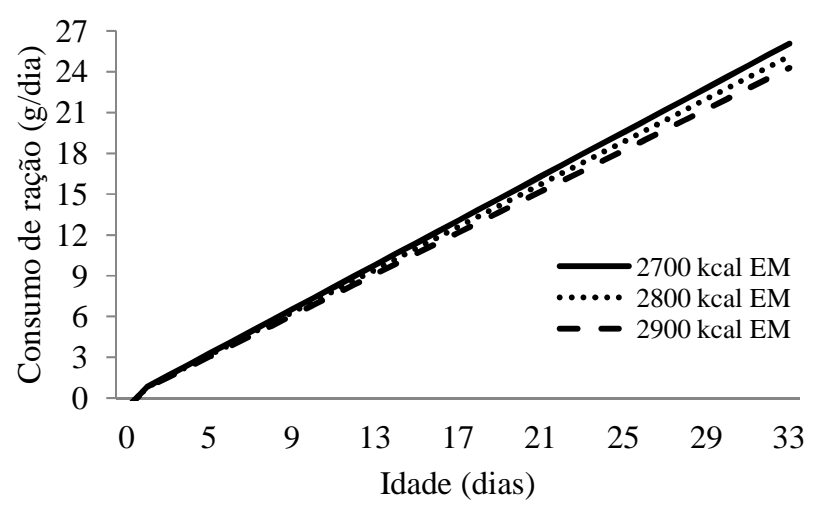

Figura 2. Consumo de ração de codornas japonesas em função da idade e do valor energético da ração

Tabela 1. Especificações nutricionais para codornas japonesas em todas as idades

\begin{tabular}{lccccc}
\hline Nutriente & $\begin{array}{c}\text { Inicial } \\
(1 \mathrm{a} 21 \text { dias })\end{array}$ & $\begin{array}{c}\text { Crescimento } \\
(22 \mathrm{a} 42 \text { dias })\end{array}$ & $\begin{array}{c}\text { Período total } \\
(1 \mathrm{a} 42 \text { dias })\end{array}$ & Postura 1 & Postura 2 \\
\hline PB $(\%)$ & 25 & 22 & 23 & 20 & 23 \\
EMAn $(\mathrm{kcal} / \mathrm{kg})$ & 2.900 & 3.050 & 2.950 & 2.800 & 2.950 \\
Cálcio $(\%)$ & 0,60 & 0,50 & 0,55 & 2,95 & 3,20 \\
P disponível $(\%)$ & 0,30 & 0,25 & 0,26 & 0,35 & 0,40 \\
Sódio $(\%)$ & 0,14 & 0,14 & 0,14 & 0,23 & 0,25 \\
Cloro $(\%)$ & 0,15 & 0,15 & 0,15 & 0,24 & 0,26 \\
Potássio $(\%)$ & 0,45 & 0,45 & 0,45 & 0,46 & 0,50 \\
Magnésio $(\mathrm{ppm})$ & 300 & 300 & 300 & 500 & 550 \\
\hline Bal. elet. $(\mathrm{mEq} / \mathrm{kg})$ & 133,71 & 133,71 & 133,71 & 150,05 & 163,33 \\
\hline
\end{tabular}

Fonte: Silva e Costa (2009).

$\mathrm{PB}=$ proteína bruta; EMAn = energia metabolizável corrigida; Bal. elet. = balanço eletrolítico. 
Os aminoácidos têm várias funções no organismo, e as necessidades de formar as proteínas corporais são, quantitativamente, prioritárias. Dos 20 aminoácidos que as codornas exigem, apenas 09, são considerados essenciais (D’MELLO, 2003), e, destes, apenas as exigências de lisina e dos aminoácidos sulfurosos foram avaliadas na maioria dos estudos, enquanto, escassas pesquisas foram realizadas com treonina, triptofano e valina.

As principais funções bioquímicas da lisina, no organismo, são a formação dos tecidos muscular, ósseo e como precursor da carnitina. A lisina é o terceiro aminoácido mais tóxico para as aves (KOELKEBECECK et al., 1991), e o antagonismo com arginina causa sintomas de deficiência de arginina devido à competição por sítios de absorção nos enterócitos (KIDD \& KERR, 1998). Entretanto, com a aplicação do conceito de proteína ideal, no qual lisina é o aminoácido referência, mesmo se a exigência de lisina for alterada por fatores dietéticos, genéticos e ambientais, a relação ideal deve ser mantida. Assim, com o surgimento do conceito de proteína ideal, houve uma simplificação da atualização das exigências das aves em todos os aminoácidos. A lisina foi escolhida por ser utilizada mais para síntese proteica, pelo maior número de trabalhos publicados e sua análise ser menos dispendiosa que a de metionina e cisteína (JORDÃO FILHO et al., 2006).

A metionina é o primeiro aminoácido limitante em rações a base de milho e farelo de soja para codornas (MANDAL et al., 2005). É ainda o primeiro aminoácido da cadeia polipeptídica das proteínas, atua no transporte e doação de grupos metil para síntese de colina a partir da etanolamina, doa enxofre à serina, que resulta na síntese de cisteína, e pode ser um indicador do status nutricional do animal em vitamina $\mathrm{B}_{12}$ (D'MELLO, 2003). A metionina atende $100 \%$ das exigências em cisteína, mas o contrário não ocorre, enquanto que a proteína das penas das aves contém abundante teor de cistina (KLASING, 1998).

A treonina é considerada o terceiro aminoácido limitante em rações a base de milho e farelo de soja para frangos e perus, mas é o segundo, depois da metionina, nas rações de codornas, compostas pelos mesmos ingredientes (MANDAL et al., 2006). A treonina não possui precursores intermediários, e o isômero D não pode ser convertido no organismo para o isômero L (D'MELLO, 2003), logo, é necessário que a dieta contenha $100 \%$ das necessidades das aves. A treonina ainda está envolvida na síntese e secreção de mucina, amilase e crescimento da mucosa intestinal.

$\mathrm{Na}$ Tabela 1, observam-se reduções da proteína de 25 para $22 \%$ e, aumento da energia de 2.900 para $3.050 \mathrm{kcal}$ EMAn da fase inicial (1 a 21 dias) para a fase de crescimento (22 a 42 dias). Também, as especificações dos aminoácidos lisina, treonina, metionina, metionina+cistina, triptofano, isoleucina, fenilalanina e valina foram reduzidas da fase inicial para a fase de crescimento (Tabela 2). Para o período total (1 a 42 dias), os valores ficaram, em média, $5 \%$ acima do perfil de aminoácidos da fase de 22 a 42 dias, numa posição intermediária a fase inicial e de crescimento.

O nível de lisina sugerido, de 1,30\% para o período total de crescimento, na presente Tabela, está próximo do recomendado pelo NRC (1994), de $1,30 \%$, e inferior ao sugerido por Lázaro et al. (2005), de 1,60\%. Porém, os níveis de metionina de $0,50 \%$, metionina+cistina de $0,75 \%$, e de treonina de $1,02 \%$ estão acima dos sugeridos por Lázaro et al. (2005) de, respectivamente, 0,$38 ; 0,67$ e $0,65 \%$, e 
Rev. Bras. Saúde Prod. Anim., Salvador, v.13, n.3, p.775-790 jul./set., 2012 http://www.rbspa.ufba.br ISSN 15199940

são afins aos sugeridos pelo NRC (1994) de 0,$50 ; 0,75$ e $1,02 \%$, respectivamente.

Existem semelhanças e discrepâncias entre as especificações nutricionais para as duas espécies de codornas nas fases de crescimento e postura (Tabelas $1 \mathrm{e}$ 4). Embora as sugestões de proteína e de energia sejam iguais, os níveis de cálcio, fósforo disponível e o perfil de aminoácidos são maiores para as codornas de linhagens pesadas, os quais podem ser justificados pelas maiores taxas de ganho de peso e de crescimento muscular dessas aves, especialmente, nas primeiras quatro semanas de vida.

Tabela 2. Sugestões de aminoácidos para codornas japonesas em crescimento

\begin{tabular}{|c|c|c|c|c|c|}
\hline Proteína bruta $(\%)$ & 25 & 21 dias) & $22(2$ & 42 dias) & 24 \\
\hline EMAn (kcal/kg) & & 900 & & & 2.900 \\
\hline Aminoácidos (\%) & Total & Digestível & Total & Digestível & Total \\
\hline Arginina & 1,25 & 1,16 & 1,13 & 1,05 & 1,25 \\
\hline Histina & 0,36 & 0,33 & 0,30 & 0,28 & 0,36 \\
\hline Isoleucina & 0,98 & 0,89 & 0,81 & 0,74 & 0,98 \\
\hline Fenilalanina & 0,93 & 0,85 & 0,88 & 0,81 & 0,96 \\
\hline Fenilalanina+tirosina & 1,79 & 1,64 & 1,25 & 1,14 & 1,80 \\
\hline Leucina & 1,69 & 1,60 & 1,28 & 1,21 & 1,69 \\
\hline Lisina & 1,36 & 1,19 & 1,20 & 1,05 & 1,30 \\
\hline Metionina & 0,50 & 0,46 & 0,45 & 0,41 & 0,50 \\
\hline Metionina+cistina & 0,90 & 0,80 & 0,83 & 0,74 & 0,75 \\
\hline Treonina & 1,02 & 0,87 & 0,96 & 0,82 & 1,02 \\
\hline Triptofano & 0,22 & 0,20 & 0,17 & 0,15 & 0,22 \\
\hline Valina & 0,95 & 0,84 & 0,83 & 0,74 & 0,95 \\
\hline
\end{tabular}

Fonte: Silva e Costa (2009).

EMAn = energia metabolizável corrigida.

Os níveis dos aminoácidos digestíveis e totais da ração de codornas japonesas, por fase, são apresentadas na Tabela 2. Exceto a relação triptofano digestível: lisina digestível que caiu, e de valina e metionina que não foram alteradas, as relações dos aminoácidos sulfurados e treonina digestíveis com a lisina digestível tenderam a crescer de 1 a 21 para 22 a 42 dias.

Ao se comparar as relações dos aminoácidos digestíveis e lisina digestível sugeridas, nesta Tabela, e aquelas recomendadas por Rostagno et al. (2005) para frangas, observam-se equilíbrio na relação para alguns aminoácidos e diferenças marginais em outros casos. Por exemplo, a proporção treonina digestível: lisina digestível foi maior para codornas, enquanto que a relação metionina+cistina digestível e valina digestível: lisina digestível foi maior para frangas. Por outro lado, a comparação das exigências de codornas, de 1 a 21 dias e de 22 a 42 dias, com aquelas de frangas, de 1 a 6 e de 7 a 12 semanas é muito difícil de ser estabelecida, devido às diferenças genéticas (p. ex., peso corporal) e fisiológicas (p. ex., idade cronológica) entre as duas espécies aves. 


\section{EXIGÊNCIAS DE CODORNAS DO GENÓTIPO JAPONÊS EM POSTURA}

As exigências de energia de codornas japonesas, na fase de produção de ovos, foram estimadas em vários trabalhos realizados no Brasil, na década de 90, em seguida, o NRC (1994) divulgou a última edição da tabela com dados publicados até a metade da década de oitenta. Esforços no Brasil têm sido realizados para organizar uma Tabela de recomendação exclusiva para codornas (SILVA \& COSTA, 2009; ROSTAGNO et al., 2011).

As recomendações nutricionais de codornas japonesas durante a produção de ovos em PB, EMAn, metionina, cistina, metionina+cistina e lisina total foram mais recentemente atualizadas por Silva e Costa (2009), conforme constam na Tabela 1 a 5 . Os níveis de PB recomendados na literatura variaram de $16 \%$ até $25 \%$, enquanto as recomendações de EMAn também apresentaram elevada heterogeneidade, cuja oscilação foi de 2.600 a $3.150 \mathrm{kcal}$. Essas diferenças talvez reflitam variações genéticas, experimentais ou climáticas, que afetam o desempenho das codornas.

Silva \& Costa (2009) sugeriram equações para estimar a exigência de energia metabolizável (EM) de codornas japonesas, na fase de postura, com base em informações apresentadas por Jordão Filho et al. (2011ab). Para tanto, o peso corporal (PC), o ganho de peso (GP), a massa de ovos (MO) e a temperatura $(\mathrm{T})$ foram as principais variáveis do modelo, como se mostra a seguir: $\mathrm{EM}$ ( $\mathrm{kcal} /$ ave/dia $)=$ $\mathrm{PC}^{0,75 *(98,37-0,205 * \mathrm{~T})}+6,2 * \mathrm{GP}+$ $4,2 *$ MO. No caso de um plantel de codornas com peso médio de $0,18 \mathrm{~kg}$, ganho de peso diário de $0,04 \mathrm{~g}$, massa de ovo de 9,5 g/ave/dia e temperatura ambiente de $25^{\circ} \mathrm{C}$, o modelo proposto será: $\mathrm{EM}=0,18^{0,75} *(98,37-0,205 * 25)+$ $6,2 * 0,04+4,2 * 10,5=70,1$ com uma dieta composta de $2800 \mathrm{kcal} / \mathrm{kg}$ de EM, o consumo estimado de ração foi $25 \mathrm{~g} / \mathrm{ave} / \mathrm{dia}$. As recomendações de proteína foram de 20 e $23 \%$ para rações com, respectivamente, $2.800 \mathrm{e}$ $2.950 \mathrm{kcal}$ de EMAn (Tabela 3). O NRC (1994) sugeriu um único valor de proteína (20\%) e de EMAn (2.900kcal) nas rações de codornas japonesas em postura.

Correlações positivas entre os teores de lisina total $(\mathrm{P}<0,0134 ; 0,5510)$ e de lisina digestível $(\mathrm{P}<0,009 ; 0,5820)$ com o teor de proteína bruta da ração foram detectadas. Ribeiro et al. (2003) constataram que, ao elevar o teor de proteína da ração de 20 para $23 \%$, a exigência de lisina passou de 1,07 para $1,15 \%$, respectivamente. A cada $1 \%$ de aumento, no conteúdo de proteína da ração, as exigências de lisina digestível e total aumentaram 0,041 e 0,038\%; portanto, se uma ração é formulada com $20 \%$ de proteína são sugeridos, no mínimo, 1,08 e $0,95 \%$ e, com $23 \%$ de proteína, 1,20 e $1,05 \%$, respectivamente, de lisina total e digestível (Tabela 2).

$\mathrm{O}$ excesso de proteína ou o desequilíbrio na relação entre os aminoácidos essenciais e entre os últimos e os não essenciais aumentam o catabolismo e a perda fecal de nitrogênio. Ocorre que mais energia é desviada pelo organismo para sintetizar ácido úrico, o que torna a qualidade do ambiente nas instalações mal manejadas e mal planejadas, insuportável e pode interferir na saúde do homem e das aves (SILVA et al., 2006). 
Rev. Bras. Saúde Prod. Anim., Salvador, v.13, n.3, p.775-790 jul./set., 2012 http://www.rbspa.ufba.br ISSN 15199940

Tabela 3. Sugestões de aminoácidos para codornas japonesas em produção de ovos

\begin{tabular}{|c|c|c|c|c|c|}
\hline Nutriente & \multicolumn{2}{|c|}{ Postura 1} & \multicolumn{2}{|c|}{ Postura 2} & NRC \\
\hline Proteína bruta (\%) & \multicolumn{2}{|c|}{20} & \multicolumn{2}{|c|}{23} & 20 \\
\hline EMAn (kcal/kg) & \multicolumn{2}{|c|}{2.800} & \multicolumn{2}{|c|}{2.950} & 2900 \\
\hline Aminoácidos (\%) & Total & Dig. & Total & Dig. & Total \\
\hline Arginina & 1,35 & 1,26 & 1,48 & 1,38 & 1,26 \\
\hline Histina & 0,45 & 0,42 & 0,49 & 0,46 & 0,42 \\
\hline Isoleucina & 0,96 & 0,87 & 1,06 & 0,96 & 0,90 \\
\hline Fenilalanina & 0,83 & 0,76 & 0,91 & 0,84 & 0,78 \\
\hline Fenilalanina+tirosina & 1,56 & 1,42 & 1,72 & 1,57 & 1,40 \\
\hline Leucina & 1,52 & 1,43 & 1,67 & 1,58 & 1,42 \\
\hline Lisina & 1,08 & 0,95 & 1,20 & 1,05 & 1,00 \\
\hline Metionina & 0,42 & 0,39 & 0,46 & 0,42 & 0,45 \\
\hline Metionina+cistina & 0,78 & 0,70 & 0,80 & 0,72 & 0,70 \\
\hline Treonina & 0,79 & 0,67 & 0,86 & 0,73 & 0,74 \\
\hline Triptofano & 0,20 & 0,18 & 0,22 & 0,20 & 0,19 \\
\hline Valina & 0,98 & 0,87 & 1,06 & 0,94 & 0,92 \\
\hline
\end{tabular}

Fonte: Silva e Costa (2009).

EMAn = energia metabolizável corrigida; Dig. = digestível.

As relações metionina+cistina digestível: lisina digestível de 72 e $67 \%$, respectivamente, para as rações com $20 \mathrm{e}$ $23 \%$ de PB para codornas japonesas em postura são menores que aquela sugerida por Pinto et al. (2003) de 80\%. Ao utilizar rações com $19,5 \%$ de PB, Scottá et al. (2011) observaram bom índice de desempenho com codornas japonesas, em postura, alimentadas com relação metionina+cistina digestível: lisina digestível de $66 \%$. As relações lisina total: $\mathrm{PB}$, respectivamente, de 5,4 e $5,2 \%$ nas rações com 20 e $23 \%$ de PB, estão próximas daquela citada por Rostagno et al. (2005) para galinhas poedeiras, de $5,4 \%$, e corroboram as sugeridas por Ribeiro et al. (2003), de 5,4 a 5,0\%, para codornas japonesas, na fase de postura, alimentadas com rações, compostas de 20 e $23 \%$ de PB.
Da mesma forma, as exigências de codornas japonesas são inferiores àquelas das codornas europeias em PB, cálcio, fósforo e em todos os aminoácidos. $\mathrm{O}$ perfil ideal de aminoácido apresenta maiores proporções de todos os aminoácidos, em relação à lisina, para as codornas europeias. As relações cálcio: fósforo nas rações de baixa e de alta PB de 8,4: 1 e 8: 1 são maiores que àquela de 7: 1, citada pelo NRC (1994) para codornas, na fase de produção de ovos, entretanto, representam pouco, se comparadas aos 14: 1 citados por Rostagno et al. (2005) para galinhas poedeiras. As relações cálcio: fósforo disponíveis, do presente trabalho, são compatíveis com as citadas por Lázaro et al. (2005) de 7,7: 1. Por outro lado, a relação cálcio: fósforo de 8,3: 1 para codornas de linhagens pesadas é 
superior à relação cálcio: fósforo, sugerida para codornas japonesas.

Ao se tomar a ração para codornas, de $20 \%$ de PB, numa comparação com a ração de galinhas poedeiras recomendada por Rostagno et al. (2005), observam-se que, exceto a relação treonina: lisina digestível (70 vs. 66) e valina (92 vs. 90), as relações metionina (41 vs. 50 ), metionina+cistina (74 vs. 91) e triptofano (19 vs. 23 ) com a lisina digestível são menores nas rações de codornas. Essa última relação é compatível com o maior consumo relativo desta espécie em comparação com àquele das galinhas (15 vs. $7 \%$ ).

\section{EXIGÊNCIAS DE CODORNAS DO GENÓTIPO EUROPEU}

As codornas europeias (Figura 3a) apresentam crescimento mais rápido

a

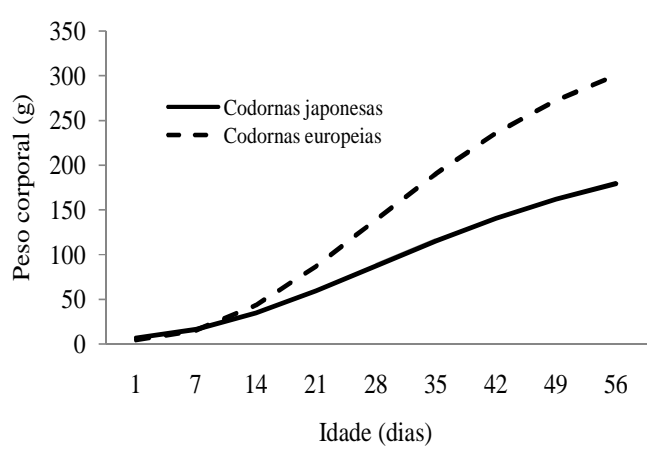

que as japonesas, em todas as idades, e ambas apresentam o pico máximo de taxa de crescimento aos 27 dias (Figura $3 b$ ), provavelmente, o período de maior deposição de proteína e água na carcaça. Em seguida, a taxa de crescimento diminui e o ganho passa a ter um retorno progressivamente decrescente, com aumentos da deposição de gordura em vísceras, retenção de nutrientes no ovário-oviduto e da exigência de energia dietética.

Aos 35 dias, o peso das codornas pesadas se aproxima de $200 \mathrm{~g}$, ou seja, cerca de 25 vezes o peso da codorna com 1 dia de idade ( $8 \mathrm{~g})$. Segundo Silva et al. (2006), as fêmeas de linhagens de codornas europeias apresentam peso $10 \%$ maior que os machos da sexta a oitava semana de vida e, por isso, devem ser abatidas mais jovens para evitar maiores perdas com o descarte de órgãos reprodutivos.

Figura 3. Curva (a) e taxa (b) de crescimento de codornas de 1 a 42 (a). À esquerda, a curva superior é referente ao crescimento de codornas europeias de 1 a 42 dias e, à direita, vê-se que a maior taxa de crescimento ocorre aos 27 dias para ambas as codornas, mas a taxa de crescimento das europeias supera a taxa das japonesas em todas as idades

Alguns estudos foram realizados no Brasil para estimar as exigências nutricionais de codornas europeias em crescimento. Estas exigem mais aminoácidos que as codornas japonesas (SILVA \& COSTA, 2009). Resultados de Jordão Filho et al. (2011a) mostraram que codornas europeias também exigiam mais 
Rev. Bras. Saúde Prod. Anim., Salvador, v.13, n.3, p.775-790 jul./set., 2012 http://www.rbspa.ufba.br ISSN 15199940

energia para mantença e eram mais eficientes no uso da energia para ganho do que as japonesas.

$\mathrm{Na}$ Tabela 4, são apresentadas as especificações nutricionais para as fases de crescimento e de postura. Em todas as fases, apesar da semelhança dos níveis de proteína e de energia recomendados na Tabela 1, para as codornas japonesas, os níveis dos aminoácidos são mais expressivos para codornas europeias, influenciados, provavelmente, pela maior taxa de crescimento e maior peso corporal destas aves.

As relações cálcio: fósforo disponível de 2: 1 para todas as fases do crescimento de codornas japonesas foram semelhantes às sugeridas para codornas europeias, exceto de 22 a 42 dias, na qual essa relação foi, por pequena margem, baixa para as codornas japonesas (2,1: 1 vs. 2,3: 1). Na fase de produção, as relações entre esses minerais foram semelhantes para ambas as espécies (8,4: 1 das japonesas vs. 8,3: 1 das europeias), ao se considerar as rações com $20 \%$ de proteína.

Tabela 4. Recomendações nutricionais para codornas europeias em todas as idades

\begin{tabular}{lcccc}
\hline Nutrientes & $\begin{array}{c}\text { Inicial } \\
(1 \mathrm{a} 21 \mathrm{~d})\end{array}$ & $\begin{array}{c}\text { Crescimento } \\
(22 \mathrm{a} 42 \mathrm{~d})\end{array}$ & $\begin{array}{c}\text { Período total } \\
(1 \mathrm{a} 42 \mathrm{~d})\end{array}$ & Postura \\
\hline Proteína bruta (\%) & 25 & 22 & 23 & 22 \\
EMAn (kcal/kg) & 2.900 & 3.050 & 2.950 & 2.900 \\
Cálcio (\%) & 0,85 & 0,70 & 0,75 & 3,50 \\
Fósforo disponível (\%) & 0,38 & 0,30 & 0,35 & 0,42 \\
Sódio (\%) & 0,17 & 0,15 & 0,16 & 0,23 \\
Cloro (\%) & 0,16 & 0,14 & 0,15 & 0,24 \\
Potássio (\%) & 0,40 & 0,40 & 0,40 & 0,46 \\
Magnésio (ppm) & 300 & 300 & 300 & 500 \\
\hline Bal. elet. (mEq/kg) & 131,14 & 128,08 & 129,61 & 150,05 \\
\hline
\end{tabular}

Fonte: Silva e Costa (2009).

EMAn = energia metabolizável corrigida; Bal. elet. = balanço eletrolítico.

As percentagens de lisina total, relativas à proteína, foram de 6,$2 ; 5,3 ; 5,6$ e $6,5 \%$, respectivamente, para a fase inicial, crescimento, período total de crescimento e produção de ovos para as codornas europeias (Tabela 5), enquanto para as codornas japonesas foram $5,4 \%$, em todas as fases desde o crescimento até a produção de ovos (ao considerar a recomendação para a postura 1). Portanto, as codornas europeias tendem a exigir maiores quantidades de lisina em relação ao conteúdo de proteína da dieta.

Novamente, a maior taxa de crescimento, especialmente, dos músculos peitorais nas codornas europeias é a possível explicação para esse resultado, devido à lisina ser utilizada para síntese de proteína corporal. Tendência semelhante foi constatada em frangos de linhagens modernas (de conformação) que exigem maior proporção de lisina na dieta em comparação com os níveis proteicos (ROSTAGNO et al., 2005).

No período de 1 a 21 dias de idade, as codornas de linhagens pesadas apresentam maiores exigências de lisina total $(1,56$ vs. $1,26 \%)$ e digestível $(1,37$ 
Rev. Bras. Saúde Prod. Anim., Salvador, v.13, n.3, p.775-790 jul./set., 2012 http://www.rbspa.ufba.br ISSN 15199940

vs. $1,15 \%)$, metionina+cistina total $(1,16$ vs. $0,90 \%)$ e digestível $(1,04$ vs. $0,81 \%)$, e de treonina total $(1,22$ vs.
$0,86 \%)$ e digestível (1,04 vs. $0,74 \%)$ que pintos de corte na fase inicial (ROSTAGNO et al., 2005).

Tabela 5. Recomendações de aminoácidos para codornas europeias em todas as idades

\begin{tabular}{|c|c|c|c|c|c|c|}
\hline & \multicolumn{2}{|c|}{ Inicial (1 a 21 d) } & \multicolumn{2}{|c|}{ Crescimento ( 22 a 42 d) } & \multicolumn{2}{|c|}{ Postura } \\
\hline Proteína bruta (\%) & \multicolumn{2}{|c|}{25} & \multicolumn{2}{|c|}{22} & \multicolumn{2}{|c|}{22} \\
\hline EMAn (kcal/kg) & \multicolumn{2}{|c|}{2.900} & \multicolumn{2}{|c|}{3.050} & \multicolumn{2}{|c|}{2.900} \\
\hline Aminoácidos (\%) & Total & Dig. & Total & Dig. & Total & Dig. \\
\hline Arginina & 2,07 & 1,92 & 1,86 & 1,73 & 1,62 & 1,51 \\
\hline Histina & 0,84 & 0,78 & 0,76 & 0,70 & 0,54 & 0,50 \\
\hline Isoleucina & 1,25 & 1,14 & 1,12 & 1,03 & 1,15 & 1,04 \\
\hline Fenilalanina & 1,50 & 1,38 & 1,35 & 1,24 & 0,99 & 0,91 \\
\hline Fenialanina+tirosina & 2,22 & 2,03 & 2,00 & 1,83 & 1,87 & 1,71 \\
\hline Leucina & 2,55 & 2,41 & 2,30 & 2,17 & 1,82 & 1,72 \\
\hline Lisina & 1,56 & 1,37 & 1,40 & 1,23 & 1,30 & 1,15 \\
\hline Metionina & 0,60 & 0,55 & 0,54 & 0,50 & 0,50 & 0,46 \\
\hline Metionina+cistina & 1,16 & 1,04 & 1,04 & 0,94 & 0,94 & 0,84 \\
\hline Treonina & 1,22 & 1,04 & 0,83 & 0,70 & 0,95 & 0,81 \\
\hline Triptofano & 0,21 & 0,19 & 0,19 & 0,17 & 0,23 & 0,20 \\
\hline Valina & 1,14 & 1,01 & 1,03 & 0,91 & 1,18 & 1,05 \\
\hline
\end{tabular}

Fonte: Silva e Costa (2009).

EMAn = energia metabolizável corrigida, Dig. = digestível.

As sugestões de energia desta Tabela $(2.950$ e $2.900 \mathrm{kcal})$, de proteína bruta (23 e 24\%), de lisina total $(1,30$ e $1,30 \%)$, para o período total de crescimento (1 a 42 dias), de energia (2.900 vs. 2.900) e de proteína $(20$ e $20 \%$ ), para a fase de postura (postura 1), são muito semelhantes àquelas sugeridas pelo NRC (1994) para codornas japonesas.

\section{EXIGÊNCIAS DE VITAMINAS}

Como nas outras espécies de aves, as vitaminas exercem funções metabólicas diversas nas codornas. Atuam como precursoras ou como coenzimas nos processos metabólicos dos nutrientes.

Nas aves sob estresse calórico, a utilização das vitaminas e o consumo de ração caem, e as perdas endógenas de muitas vitaminas aumentam, o que altera, portanto, as exigências. Por outro lado, o estresse associado às infecções prejudica a absorção, especialmente, das vitaminas lipossolúveis, bem como aumenta as necessidades das aves para muitas vitaminas (KLASING, 1998). As micotoxinas também aumentam a exigência de codornas para alguns tipos específicos de vitaminas, p.ex., a fumonisina $B_{1}$ eleva a necessidade de 
Rev. Bras. Saúde Prod. Anim., Salvador, v.13, n.3, p.775-790 jul./set., 2012 http://www.rbspa.ufba.br ISSN 15199940

ácido fólico (BUTKERAITIS et al., 2004).

A similaridade química aumenta o potencial de interação entre algumas vitaminas, duas dessas interações são conhecidas e relevantes: (i) colina, vitamina $B_{12}$ e ácido fólico interagem no metabolismo dos grupos Metil; e (ii) as vitaminas lipossolúveis competem por sítios de absorção e excessos de uma, eleva as exigências das outras (D’MELLO, 2003). A interação entre a vitamina E e Selênio, comprovada nas outras aves, também deve ocorrer no organismo de codornas.

As recomendações de vitaminas para crescimento e produção de ovos de codornas são mostradas na Tabela 6 .

Tabela 6. Recomendações de vitaminas para codornas européias em todas as idades

\begin{tabular}{lccccc}
\hline & \multicolumn{3}{c}{ Crescimento } & \multicolumn{3}{c}{ Produção de ovos } \\
\hline \multirow{2}{*}{ Vitaminas Lipossolúveis } & $\begin{array}{c}\text { Silva et al. } \\
(2009)\end{array}$ & $\begin{array}{c}\text { NRC } \\
(1994)\end{array}$ & $\begin{array}{c}\text { Silva et al. } \\
(2009)\end{array}$ & $\begin{array}{c}\text { NRC } \\
(1994)\end{array}$ & $\begin{array}{c}\text { Ind. } \\
\text { Bras. }\end{array}$ \\
\hline A (UI) & 850 & 1.650 & 1.650 & 3.300 & 7.000 \\
$\mathrm{D}_{3}(\mathrm{UI})$ & 300 & 750 & 250 & 900 & 2.100 \\
$\mathrm{E}(\mathrm{UI})$ & 45 & 12 & 75 & 25 & 50 \\
$\mathrm{~K}_{3}(\mathrm{mg} / \mathrm{kg})$ & 0,55 & 1,5 & 1,5 & 1 & 2 \\
\hline Vitaminas & & & & & \\
Hidrossolúveis & & & & & \\
\hline B $_{12}(\mathrm{mg} / \mathrm{kg})$ & 0,004 & 0,003 & 0,002 & 0,003 & 3 \\
Biotina $(\mathrm{mg} / \mathrm{kg})$ & 0,30 & 0,30 & 0,10 & 0,15 & 0,10 \\
Colina $(\mathrm{mg} / \mathrm{kg})$ & 1.300 & 2.000 & 2.090 & 1.500 & 1.500 \\
Folacina $(\mathrm{mg} / \mathrm{kg})$ & 0,36 & 1 & 0,3 & 1 & 1 \\
Niacina $(\mathrm{mg} / \mathrm{kg})$ & 15 & 40 & 9 & 20 & 39,8 \\
Ác. pantotênico $(\mathrm{mg} / \mathrm{kg})$ & 5 & 10 & 4,5 & 15 & 15,6 \\
Piridoxina $(\mathrm{mg} / \mathrm{kg})$ & 2,5 & 3 & 3 & 3 & 4 \\
Riboflavina $(\mathrm{mg} / \mathrm{kg})$ & 5 & 4 & 2,5 & 4 & 3 \\
\hline
\end{tabular}

Fonte: Silva e Costa (2009).

\section{EXIGÊNCIAS DE MINERAIS}

Vários fatores podem afetar as exigências de minerais, a saber: $o$ estresse pelo calor e o antagonismo mineral. Resultados do experimento de Sahin et al. (2004) com codornas, em crescimento, indicaram que a excreção de cálcio passou de 0,95 para 2,35; de fósforo de 0,29 para 0,47; de magnésio de 0,12 para 0,20 ; de zinco de 3,64 para 4,97; de ferro de 20,6 para 28,5; e cromo de 0,04 para $0,09 \mathrm{mg} / \mathrm{kg} / \mathrm{ave} / \mathrm{dia}$.
Segundo Hamilton et al. (1979), o excesso de zinco tem efeito antagônico ao cobre, ferro e manganês e provoca redução do crescimento, da pigmentação das penas e causa perose $\mathrm{e}$ anemia severa em codornas.

As recomendações de cálcio, fósforo disponível, potássio, magnésio, cloro e sódio para codornas japonesas são mostradas na Tabela 1 e das europeias na Tabela 4, enquanto as sugestões dos microminerais para codornas são apresentadas na Tabela 7 . 
Rev. Bras. Saúde Prod. Anim., Salvador, v.13, n.3, p.775-790 jul./set., 2012 http://www.rbspa.ufba.br ISSN 15199940

Tabela 7. Níveis mínimos de microminerais para todas as fases criação de codornas

\begin{tabular}{lcc}
\hline Minerais (ppm) & Silva \& Costa (2009) & NRC (1994) \\
\hline Crescimento & & \\
\hline Ferro & 95 & 120 \\
Iodo & 1,0 & 0,3 \\
Cobre & 3,6 & 5,0 \\
Manganês & 6,8 & 60 \\
Zinco & 30 & 25 \\
Selênio & 1,0 & 0,2 \\
Cobalto & 0,20 & - \\
\hline Produção & & 60 \\
\hline Ferro & 95 & 0,3 \\
Iodo & 1,0 & 5,0 \\
Cobre & 3,6 & 60 \\
Manganês & 6,8 & 50 \\
Zinco & 30 & 0,2 \\
Selênio & 0,50 & - \\
Cobalto & 0,20 & \\
\hline
\end{tabular}

Fonte: Silva \& Costa (2009).

Os resultados desta revisão permitiram concluir que as codornas pesadas exigem mais aminoácidos nas rações que as codornas melhoradas para a produção de ovos e, ambas, possuem necessidades de proteína e de cálcio distintas daquelas de frangos e de galinhas. Assim, rações formuladas para estas duas últimas espécies não devem ser fornecidas às codornas;

Sugere-se a realização de pesquisas com nutrientes como os aminoácidos essenciais treonina, triptofano, valina, isoleucina e tirosina, além de ácidos graxos essenciais, vitaminas e minerais.

\section{AGRADECIMENTOS}

$\grave{A}$ Ajinomoto pelo apoio financeiro a este projeto. Ao $\mathrm{CNPq}$ pela bolsa em produtividade e pesquisa e aos pesquisadores brasileiros pelo trabalho dedicado ao estudo da nutrição de codornas.

\section{REFERÊNCIAS}

AGGREY, S.E.; ANKRA-BADU, G.A.; MARKS, H.L. Effect of longterm divergent selection on growth characteristics in Japanese quail. Poultry Science, v.82, p.538-542, 2003.

BUTKERAITIS, P.; OLIVEIRA, C.A.F; LEDOUX, D.R.; OGIDO, R.; ALBUQUERQUE, R.; ROSMANINHO, J.F.;

ROTTINGHAUS,G.E. Effect of dietary fumonisin B1 on laying japanese quail. British Poultry Science, v.45, p.798-801, 2004.

D'MELLO, J.P.F. Amino acids in animal nutrition. $2^{\text {nd }} \mathrm{ed}$. Wallingford: CABI Publishing, 2003. 546p. 
ELANGOVAN, A.V.; MANDAL, A.B.; TYAGI, P.K.; TYAGI, P.K.; TOPPO, S.; JOHRI, T.S. Effects of enzymes in diets with varying energy levels on growth and egg production performance of Japanese quail. Journal of the Science and Food and Agriculture, v.84, p.2028-2034, 2004.

FREITAS, A.C.; FUENTES, M.F.F.; FREITAS, E.R.; SUCUPIRA, F.S.; OLIVEIRA, B.C.M. Efeitos de níveis de proteína bruta e energia metabolizável na dieta sobre o desempenho de codornas de postura. Revista Brasileira de Zootecnia, v.34, p.838-846, 2005.

GARCIA, E.A.; MENDES, A.A.; PIZZOLANTE, C.C.; SALDANHA, E.S.P.B.; MOREIRA, J.; MORI, C.; PAVAN, A.C. Protein, methionine+cystine and lysine levels for japanese quails during the production phase. Brazilian Journal of Poultry Science, v.7, p.11-18, 2005.

HAMILTON, R.P.; FOX, M.R.S.; FRY JR., B.E.; JONES, A.O.L.; JACOBS, R.M. Zinc interference with copper, iron and manganese in young Japanese quail. Journal of food science, v.44, p.738-741, 1979.

JORDÃO FILHO, J.; SILVA, J.H.V.; SILVA, C.T.; COSTA, F.G.P.; SOUSA, J.M.B.; GIVISIEZ, P.E.N. Energy requirement for maintenance and gain for two genotypes of quails housed in different breeding rearing systems. Revista Brasileira de

Zootecnia, v.40, n.11, p.2415-2422, 2011a.
JORDÃO FILHO, J.; SILVA, J.H.V.; COSTA, F.G.P; KAZUE SAKOMURA, N.; SILVA, C.T.; CHAGAS, N.A.

Prediction equations to estimate the demand of energy and crude protein for maintenance, gain and egg production for laying Japanese quails. Revista Brasileira de Zootecnia, v.40, n.11, p.2423-2430, 2011 b.

JORDÃO FILHO, J.; SILVA, J.H.V.; SILVA, E.L.; RIBEIRO, M.L.G.; COSTA, F.G.P.; RODRIGUES, P.B. Exigência de lisina para poedeiras semipesadas durante o pico de postura. Revista Brasileira de Zootecnia, v.35, n.4, p.1728-1734, 2006. Supl.

KADAM, M.M.; MANDAL, A.B.; ELANGOVAN, A.V.; KAUR, S. Response of laying Japanese quail to dietary calcium levels at two levels of energy. Journal of Poultry Science, v.43, p.351-356, 2006.

KIDD, M.T.; KERR, B.J. Dietary arginine and lysine ratios in large white toms. 2. Lack interaction between arginie: lysine ratios and electrolyte balance.

Poultry Science, v.77, p.864-869, 1998.

KLASING, K. Comparative avian nutrition. Wallingford: CABI Publishing, 1998. 350p.

KOELKEBECK, K.W.; BAKER, D.H.; HAN, Y. Research note: effect of excess lysine, methionine, threonine, or tryptophan on production performance of laying hens. Poultry Science, v.70, p.1651-1653, 1991.

LÁZARO, R.; SERRANO, M.P.; CAPDEVILA, J. Nutrición y alimentación de avicultura complementaria: codornices. Madrid: Universidad Politécnica de Madrid, 2005. p.369-408. 
LIMA, R.B.; LIMA, D.F.; SILVA, J.H.V.; LACERDA, P.B.; SANTOS, R.A.; SARAIVA, E.P.; SILVA, C.T. Influência da temperatura e do balanço eletrolítico sobre o desempenho de codornas europeias (Coturnix coturnix coturnix). In: REUNIÃO ANUAL DA SOCIEDADE BRASILEIRA DE ZOOTECNIA, 46., 2009, Maringá. Anais... Maringa: Socieddae Brasileira de Zootecnia, 2009.

LOPES, I.R.V.; FUENTES, M.F.F.; FREITAS, E.R.; SOARES, M.B.; RIBEIRO, P.S. Efeito da densidade de alojamento e do nível de energia metabolizável da ração sobre o desempenho zootécnico e características dos ovos de codornas japonesas. Revista Ciência Agronômica, v.37, p.369-375, 2006.

MANDAL, A.B.; KAUR, S.; JOHRI, A.K.; ELANGOVAN, A.V.; DEO, C.; SHRIVASTAVA, H.P. Response of growing Japanese quails to dietary concentration of L-threonine. Journal of the Science and Food and Agriculture, v.86, p.793-798, 2006.

MANDAL, A.B.; ELANGOVAN, A.V.; TYAGI, P.K.; TYAGI, P.K.; TYAGI, A.K.J.; KAUR, S. Effect of enzyme supplementation on the metabolizable energy contento of solvent-extracted rapeseed and sunflower seed meals for chicken, guinea fowl and quail. British Poultry Science, v. 46, p.75-79. 2005.

MINVIELLE, F.; OGUZ, Y. Effect of genetics and breeding on egg quality of Japanese quail. World's Poultry Science Journal, v.58, p.291-295. 2002.

NATIONAL RESEARCH COUNCIL NRC. Nutrient requirements of poultry. 9.ed. Washington: National Academy of Sciences, 1994. p.44-45.
PINTO, R.; DONZELE, J.L.; FERREIRA A.S.; ALBINO, L.F.T.; SOARES, R.T.R.N.; SILVA, M.A.; PEREIRA, T.A. Exigência de metionina mais cistina para codornas japonesas em postura. Revista Brasileira de Zootecnia, v.32, n.5, p.1166-1173, 2003.

RIBEIRO, M.L.G.; SILVA, J.H.V.; DANTAS, M.O.; COSTA, F.G.P.; OLIVEIRA, S.F.; JORDÃO FILHO, J.; SILVA, E.L. Exigências nutricionais de lisina para codornas durante a fase de produção em função do nível de proteína da ração. Revista Brasileira de Zootecnia, v.32, n.1, p.156-161, 2003.

ROSTAGNO, H.S.; ALBINO, L.F.T.; DONZELE, J.L.; GOMES, P.C.; OLIVEIRA, R.F.; LOPES, D.C.; FERREIRA, A.S.; BARRETO, S.L.T.; EUCLIDES, R.F. Tabelas brasileiras para aves e suínos: composição de alimentos e exigências nutricionais. 2.ed. Viçosa, MG: Universidade Federal de Viçosa, 2005. 186p.

ROSTAGNO, H.S.; ALBINO, L.F.T.; DONZELE, J.L.; GOMES, P.C.; OLIVEIRA, R.F.; LOPES, D.C.; FERREIRA, A.S.; BARRETO, S.L.T.; EUCLIDES, R.F. Tabelas brasileiras para aves e suínos: composição de alimentos e exigências nutricionais. 3.ed. Viçosa, MG: Universidade Federal de Viçosa, 2011. 252p.

SAHIN, N.; ONDERCI, M.; SAHIN, K.; GURSU, M.F.; SMITH, M.O. Ascorbic acid and melatonin reduce heat-induced performance inhibition oxidative stress in Japanese quail.

British Poultry Science, v.45, p.116122. 2004. 
SILVA, E.L.; SILVA, J.H.V.; JORDÃO FILHO, J.; RIBEIRO, M.L.G.; COSTA, F.G.P.; RODRIGUES, P.B. Redução dos níveis de proteína e suplementação aminoacídica em rações para codornas européias (Coturnix coturnix coturnix). Revista Brasileira de Zootecnia, v.35, n.3, p.822-829, 2006.

SCOTTÁ, B.A.; VARGAS JR, J.G.; PETRUCCI, F.B.; DEMUNER, L.F.; COSTA, F.G.P.; BARBOSA, W.A.; MARIN, J.F.V. Metionina mais cistina digestível e relação metionina mais cistina digestível: lisina para codornas japonesas. Revista Brasileira de Saúde e Produção Animal[Online], v.12, n.3, p.729-738, 2011.

SILVA, J.H.V.; COSTA, F.G.P. Tabela para codornas japonesas e européias. 2.ed. Jaboticabal, SP: FUNEP, 2009. 110 p.

SILVA, J.H.V.; SILVA M.B.; JORDÃO FILHO, J.; SILVA, E.L.; ANDRADE, I.S.; MELO, D.A.; RIBEIRO, M.L.G.; ROCHA, M.R.F.; COSTA, F.G.P.; DUTRA JUNIOR, W.M. Exigência de mantença e de ganho de proteína e de energia em codornas japonesas (Coturnix coturnix japonica) na fase de 1 a 12 dias de idade. Revista Brasileira de Zootecnia, v.33, n.5, p.1209-1219, 2004a.
SILVA, J.H.V.; SILVA M.B.; JORDÃO FILHO, J.; SILVA, E.L.; ANDRADE, I.S.; MELO, D.A.; RIBEIRO, M.L.G.; ROCHA, M.R.F.; COSTA, F.G.P.; DUTRA JUNIOR, W.M. Exigência de mantença e ganho de proteína e de energia em codornas japonesas (Coturnix coturnix japonica) na fase de 15 a 32 dias. Revista Brasileira de Zootecnia, v.33, n.5, p.1220-1230, 2004b.

SILVA, V.K.; SILVA, J.D.T.; GRAVENA, R.A.; MARQUES, R.H.; HADA, F.H.; MORAES, V.M.B.

Desempenho de frangos de corte de 1 a 21 dias de idade alimentados com rações contendo extrato de leveduras e prebiótico e criados em diferentes temperaturas. Revista Brasileira de Zootecnia, v.38, n.4, p.690-696, 2009.

SILVA, J.H.V.; JORDÃO FILHO, J.; SILVA, C.T.; SOUSA, J.M.B.; COSTA, F.G.P.; SILVA, E.L. Efeito da densidade de alojamento sobre o desempenho de codornas japonesas de 1 a 14 dias de idade. In: SIMPÓSIO

INTERNACIONAL, 2, CONGRESSO

BRASILEIRO DE COTURNICULTURA, 2, 2007, Lavras. Anais... Lavras, 2007. p.143.

Data de recebimento: 10/11/2011

Data de aprovação: 29/05/2012 